\title{
INHERITANCE AND GENE ACTION FOR YIELD AND ITS ATTRIBUTES IN THREE BREAD WHEAT CROSSES (Triticum aestivum L.). Koumber, R. M. ${ }^{1}$ and A.A. El-Gammaal ${ }^{2}$ \\ ' Wheat Research Dept., Field Crops, Research Institute, A.R.C. Egypt. ${ }^{2}$ Agronomy Dept;, Faculty of Agriculture, Tanta University, Egypt.
}

\begin{abstract}
The present investigation was carried out at El-Gemmeiza Agricultural Research station, Agricultural Research Center (ARC), Egypt during four successive seasons from 2007/2008 through 2010/2011. Three crosses were used among five parental varieties, namely $\mathrm{P}_{1} \times \mathrm{P}_{2}(1), \mathrm{P}_{3} \times \mathrm{P}_{4}(2)$ and $\mathrm{P}_{4} \times \mathrm{P}_{5}(3)$ five populations $\left(\mathrm{P}_{1}, \mathrm{P}_{2}\right.$, $F_{1}, F_{2}$ and $F_{3}$ ) for each cross were used in this investigation. Highly significant heterotic values in positive direction were found for all charcters except for plant height and 1000-grain yield in the first cross, spike length in the second cross, and plant height, No. of grains/spike and No. of spikes/plant in the third cross. Over domenance for all characters except plant height and 1000-grain weight in the first cross, spike length in the second cross and No.of grains /spike in the third cross was detected. Inbreeding depression was obtained in two out of three crosses for spike length, No.of grains/spike, No.of spikes/plant, 1000-grain weight and grain yield/plant and in one out of the three crosses for plant height. The important roles of both additive and non-additive gene actionwere found in certain studied traits. Significant positive $F_{2}$ deviation $\left(E_{1}\right)$ were indicated for plant height in the third cross, No.of spikes/pant and grain yield/plant in the second and third crosses and 1000-grain weight in the first and third crosses. High to medium values of heritability estimates were found to be associated with high and moderate expected and actual gain in most traits. These obtained results indicated that, these traits could be used in the early generations, but would be more effective if postponed to late generations.
\end{abstract}

Keywords: Wheat, Heterosis, GCA, SCA, Heterosis, Heritability, Inbreeding depression, Gene action.

\section{INTRODUCTION}

Increasing grain yield of cereal crops is an important national goal to face the increasing food needs of Egyptian population. Wheat production in Egypt increased from 6.75 million ton in 2009/2010 to 9 million ton in 2010/2011 season, 33 \% increase (statistical Data, 2011, ARC, Giza). This increase was achieved both by increasing wheat area and the continuous rise in grain yield ha-1 as a result of cultivating high yield genotypes and improved cultural practices at newly reclaimed areas. Wheat breeders are always looking for means and sources of genetic improvements in grain yield and its components. Genetic diversity is the main tool for breeders to have better recombinants by creating heritable variability upon which selection can be practiced. Knowledge of genetic relationship among individuals or populations is essential to breeders for planning crosses to gain better selections for high yield and developing new promising lines.

Information regarding nature and magnitude of genetic effects prevailing in the breeding material is necessary to decide the kind of breeding 
procedure to be chosen for better exploitation of the genetic potential of different plant traits in a crop. Elhosary et al (2000) found that grain yield and its components in daillel cross among 8 parenrs, were controlled by both additive and non-additive gene effects. Akhtar and Chowdhry (2006) reported that most of the plant traits exhibited simple inheritance with additive dominance model. The additive or additive $x$ additive gene effects were important for plant height to improve grain yield in both crosses as well as their reciprocals. Manal (2009) reported that The traits which had high heritability and also showed high expected genetic advance could be substantially considered or making selections as these traits were mainly influenced by the major effects of additive gene action.

This work was conducted to study genetic variance, gene action, heritability and comparison between actual and expected genetic gain of three bread crosses derived from five parental bread wheat genotypes using five populations of each cross. The ultimate goal of this study is to elucidate the breeding value of crosses that could be utilized in breeding programs to improve wheat yield.

\section{MATERIALS AND METHODS}

The present investigation was carried out at El-Gemmeiza Agricultural Research Station, Agricultural Research Center (ARC), Egypt during four successive seasons from 2007/2008 through 2010/2011. The names and pedigree of the six parental varieties and three crosses are presented in Table 1.

Table (1): The names and pedigree of varieties and / or lines evaluated

\begin{tabular}{|c|l|c|}
\hline No & \multicolumn{1}{|c|}{ Variety of cross and pedigree } & Origin \\
\hline P1 & Chil/2*Star.CM//2793-otopy-22M-020Y-010-4Y-010M-0AP & Syria \\
\hline P2 & $\begin{array}{l}\text { Giza168 MRL/BUC//SERI } \\
\text { CM93046-8M-OY-OM-2Y-OB-OGZ }\end{array}$ & Egypt \\
\hline P3 & $\begin{array}{l}\text { Mayon-1. } \\
\text { CM58924-2Ap-1Ap-2Ap-2Ap-OAp }\end{array}$ & CIMMYT \\
\hline P4 & $\begin{array}{l}\text { Cs/E.GIG//2*CNO79/3/Ald(46)/4/BUC/BJY.CIGM86-Y54-1Y-1B- } \\
\text { 3Y-1B-1Y-0Y-3P-0Y. }\end{array}$ & CIMMYT \\
\hline P5 & $\begin{array}{l}\text { Gemmeiza 7 CMH74A.630/SX//SERI 82/AGENT } \\
\text { CGM4611-2GM-3GM-1GM-0GM }\end{array}$ & Egypt \\
\hline
\end{tabular}

In the first season (2007/08), the parental genotypes were crossed to obtain $F_{1}$ seeds, in the second season (2008/09), the hybrid seed of the three crosses were sown to give the $F_{1}$ plants. These plants were selfed to produce $F_{2}$ seeds. Moreover, the same parents were crossed to have enough $F_{1}$ seeds. The new hybrid seed and part of seeds obtained from $F_{1}$ selfed plants $\left(F_{2}\right.$ seeds) were kept in refrigerator to the final experiment. In the third season $(2009 / 10)$ three $F_{1}$ seeds were sown to produce $F_{1}$ plants, which were selfed to produce $F_{2}$ seeds. In addition, the $F_{1}$ and $F_{2}$ plants were selfed to produce $F_{2}$ and $F_{3}$ seeds, respectively. In the fourth seasons (2010/11) the 
obtained seeds of the five populations $P_{1}, P_{2}, F_{1}, F_{2}$ and $F_{3}$ of the three crosses were evaluated using a randomized complete block design with three replications. Rows were $4 \mathrm{~m}$ long; spaces between rows were $20 \mathrm{~cm}$. The plants within rows were $10 \mathrm{~cm}$ apart. Two rows were devoted for each parent and $F_{1}$ progenies, ten rows for $F_{2}$ generation and 20 rows for $F_{3}$ families for each cross. Data were recorded on individual guarded plants for plant height, spike length, No. of grains/spike, No. of spikes/plant, 1000-grain weight (g) and grain yield/plant $(\mathrm{g})$.

Various biometrical parameters in this study would only be calculated if the $F_{2}$ genetic variance was found to be significant. Heterosis was expressed as the percentage deviation of $F_{1}$ mean performance from better parent values (heterobeltiosis). Inbreeding depression was measured as the average percent decrease of the $F_{2}$ from the $F_{1}$. The T-test was used to determine the significance of these deviations where the standard error (S.E) was calculated as follows:

S.E for better parent heterosis

$$
\left.\overline{\overline{F_{1}}}-\overline{B P}=\overline{(\overline{V F}}+\overline{V B P}\right)^{1 / 2} \text { and S.E for inbreeding depression }
$$

Potence ratio $(P)$ was also calculated according to Peter and Frey (1966). In addition, $F_{2}$ deviation (E1) and $F_{3}$ deviation (E2) were measured as suggested by Mather and Jinks (1971).

Type of gene effects was estimated according to Hayman model in 1958 as described by Singh and Chaudhary (1985) as follows:

The standard error of additive-additive $x$ dominance $(d)$, dominance $(h)$, dominance $\mathrm{x}$ dominance (I) and additive $\mathrm{x}$ additive (i) is obtained by taking the squares root of respective ' $T$ ' test values are calculated upon dividing the effects of $d, h, I$ and $i$ by their respective standard error.

$$
\begin{aligned}
& \mathrm{m}=\overline{\mathrm{F}_{2}} \\
& \left.\mathrm{~d}=1 / 2 \overline{\mathrm{P}_{1}}-1 / 2 \overline{\mathrm{P}_{2}} \overline{-} \overline{\mathrm{F}_{3}}\right) \\
& \mathrm{h}=1 / 6\left(4 \overline{\mathrm{F}_{1}}+12 \overline{\mathrm{F}_{2}}-16 \overline{\mathrm{F}_{3}}\right) \\
& \mathrm{I}=1 / 3\left(16 \overline{\mathrm{F}_{3}}-24 \overline{\mathrm{F}_{2}}+8 \overline{\mathrm{F}_{1}}\right) \\
& \mathrm{i}=\overline{\mathrm{P}_{1}}-\overline{\mathrm{F}_{2}}+1 / 2\left(\overline{\mathrm{P}_{1}}-\overline{\mathrm{P}_{2}}+\mathrm{h}\right)-1 / 4 \mathrm{I}
\end{aligned}
$$

The variances of these estimates were computed as follows:

$$
\begin{aligned}
& \mathrm{Vm}=\overline{\mathrm{VF}_{2}} \\
& \mathrm{Vd}=1 / 4\left(\overline{\mathrm{VP}_{1}}+\overline{\mathrm{VP}_{2}}\right) \\
& \mathrm{Vh}=1 / 36\left(16 \overline{\mathrm{VF}_{1}}+144 \overline{\mathrm{VF}_{2}}+256 \overline{\mathrm{VF}_{3}}\right) \\
& \mathrm{VI}=1 / 9\left(256 \overline{\mathrm{VF}_{3}}+57 \overline{\mathrm{VF}_{2}}+64 \overline{\mathrm{VF}_{1}}\right) \\
& \mathrm{VI}=\overline{\mathrm{VP}_{1}}+\overline{\mathrm{VF}_{2}}+1 / 4\left(\overline{\mathrm{VP}_{1}}+\overline{\mathrm{VP}_{2}}+\mathrm{Vh}\right)+1 / 16 \mathrm{VI}
\end{aligned}
$$




\section{Koumber, R. M. and A.A. El-Gammaal}

Heritability was calculated in both broad and narrow sense according to Mather (1949) and parent off-spring regression according to Sakai (1960). Furthermore, the expected and actual genetic advance $(\Delta \mathrm{g})$ was computed according to Johanson et al. (1955).

Likewise, the genetic gain represented as percentage of the $F_{2}$ and $F_{3}$ mean performance $(\Delta \mathrm{g} \%)$ and was estimated using the method of Miller et al. (1958).

\section{RESULTS AND DISCUSSION}

Parental defferences in response to their genetic background were found to be significant in most characters under investigation. The $F_{2}$ genetic variances were also significant for all studied characters in three crosses. Means and variances of the five populations $\left(P_{1}, P_{2}, F_{1}, F_{2}\right.$ and $\left.F_{3}\right)$ for the studied characters in the three crosses are presented in Table 2. The results showed that for the first cross $\left(\mathrm{P}_{1} \times \mathrm{P}_{2}\right) ; \mathrm{P}_{2}$ variety recorded higher mean values for spike length, No.of grains/spike, No.of spikes/plant and grain yield/plant than $P_{1}$. While $P_{1}$ variety revealed higher values for plant height and 1000 -grain weight than $P_{2}$. Similarly $F_{1}$ was higher than parents, $F_{2}$ and $\mathrm{F}_{3}$ for spike length, No.of grains/spike, No.of spikes/plant and grain yield/plant. The $F_{2}$ was higher value than their parents, $F_{1}$ and $F_{3}$ for 1000 grain weight, while the $F_{3}$ exceeded all population in plant height.

With regard to two crosses $\left(\mathrm{P}_{3} \times \mathrm{P}_{4}\right)$ and $\left(\mathrm{P}_{4} \times \mathrm{P}_{5}\right)$; the mean performance of $\mathrm{P}_{2}$ variety recorded higher values for plant height, spike length, No.of spikes/plant, 1000-grain weight and grain yield/plant than $P_{1}$ variety for cross $\left(\mathrm{P}_{3} \times \mathrm{P}_{4}\right)$, plant height, No.of grains/spike, 1000-grain weight and grain yield/plant than $P_{1}$ variety for cross $\left(P_{4} \times P_{5}\right)$. The $F_{1}$. Was hiegher value than their parents, $\mathrm{F}_{2}$ and $\mathrm{F}_{3}$ for plant height, No.of grains/spike, 1000-grain weight and grain yield/plant for cross $\left(\mathrm{P}_{3} \times \mathrm{P}_{4}\right)$, spike length, No.of spikes/plant and 1000 -grain weight for cross $\left(\mathrm{P}_{4} \times \mathrm{P}_{5}\right)$. The $\mathrm{F}_{2}$ was higher than $\mathrm{F} 3$ in plant height, spike length and No.of spikes/plant and exceeded all populations in No.of spikes/plant and 1000-grain weight for cross $\left(\mathrm{P}_{3} \times \mathrm{P}_{4}\right)$. While $\mathrm{F}_{3}$ was higher than $F_{2}$ in No.of grains/plant and exceeded all population in plant height for cross $\left(\mathrm{P}_{4} \times \mathrm{P}_{5}\right)$. Therefor selection could be effective in the improvement of the characters spike length, No.of grains/spike, No.of spikes/plant and grain yield/plant in the next generation. The data also revealed that the variance of $F_{2}$ and $F_{3}$ respectivly was larger for all characters than $P_{1}, P_{2}$ and $F_{1}$. This indicates that the environmental fluctuation have marked effects on the expression of these characters. These results are in harmony with those obtained by Abdel-Nour, Nadya and Moshref (2006).

Heterosis, potence ratio $(P)$, inbreeding depression percentage, $E_{1}$, $\mathrm{E}_{2}$ and different gene actions for the six characters are given in Table 3. It could be observed from the data that highly significant heterotic values in positive direction were found for all charcters except for plant height and 1000-grain weight in the first cross, spike length in the second cross, and plant height and No.of grains/spike in the third cross. Similar trends were reported by Abdel-Nour, Nadya et al. (2005). 
Table 2 : Number, means and variance for some studied characters using the five population (P1, P2, F1, F2 and bulked F3 crosses. families) for three bread wheat

\begin{tabular}{|c|c|c|c|c|c|c|}
\hline \multirow{2}{*}{ Character } & \multirow[b]{2}{*}{$\mathbf{n}$} & \multicolumn{5}{|c|}{ P1xP2 } \\
\hline & & P1 & P2 & F1 & F2 & F3 bulk \\
\hline \multirow{2}{*}{ Plant height } & $x^{-}$ & 115.57 & 104.22 & 108.45 & 109.79 & 121.55 \\
\hline & S2 & 21.79 & 35.23 & 5.96 & 182.69 & 140.89 \\
\hline \multirow{2}{*}{ Spike length } & $x$ & 14.43 & 14.57 & 18.57 & 11.28 & 12.87 \\
\hline & S2 & 0.69 & 0.89 & 0.79 & 2.14 & 1.85 \\
\hline \multirow{2}{*}{ No. of grains/spike } & $x^{-}$ & 97.51 & 98.67 & 123.60 & 79.95 & 75.71 \\
\hline & S2 & 32.57 & 50.69 & 48.24 & 331.25 & 210.11 \\
\hline \multirow{2}{*}{ No. of spikes/plant } & $x^{-}$ & 7.13 & 9.40 & 13.50 & 11.16 & 8.73 \\
\hline & S2 & 2.20 & 3.21 & 2.11 & 11.60 & 7.62 \\
\hline \multirow{2}{*}{ 1000-grain weight } & $x$ & 48.40 & 45.95 & 46.24 & 50.85 & 46.71 \\
\hline & S2 & 4.20 & 3.50 & 4.00 & 20.97 & 18.09 \\
\hline \multirow{2}{*}{ Grain yield/plant } & $x^{-}$ & 32.74 & 55.57 & 60.00 & 49.05 & 43.04 \\
\hline & S2 & 9.66 & 20.37 & 23.26 & 358.70 & 276.80 \\
\hline & & \multicolumn{5}{|c|}{ P3xP4 } \\
\hline \multirow{2}{*}{ Plant height } & $x^{-}$ & 103.87 & 129.67 & 135.27 & 117.91 & 105.94 \\
\hline & S2 & 1.36 & 33.26 & 31.45 & 395.97 & 165.87 \\
\hline \multirow{2}{*}{ Spike length } & $x$ & 14.20 & 16.27 & 15.63 & 13.83 & 12.23 \\
\hline & S2 & 1.06 & 1.31 & 2.10 & 4.35 & 2.85 \\
\hline \multirow{2}{*}{ No. of grain/spike } & $x^{-}$ & 99.59 & 98.60 & 121.08 & 75.84 & 73.03 \\
\hline & S2 & 80.40 & 75.89 & 97.59 & 362.08 & 344.87 \\
\hline \multirow{2}{*}{ No. of spikes/plant } & $x^{-}$ & 7.13 & 9.40 & 9.96 & 11.31 & 11.25 \\
\hline & S2 & 2.20 & 3.21 & 2.11 & 11.98 & 7.10 \\
\hline \multirow{2}{*}{ 1000-grains weight } & $x$ & 40.22 & 41.76 & 49.53 & 45.92 & 46.61 \\
\hline & S2 & 3.75 & 9.01 & 6.33 & 22.37 & 12.65 \\
\hline \multirow{2}{*}{ Grain yield/plant } & $x^{-}$ & 26.63 & 36.75 & 58.91 & 48.14 & 48.78 \\
\hline & S2 & 15.80 & 14.59 & 22.57 & 320.49 & 314.30 \\
\hline & & \multicolumn{5}{|c|}{ P4xP5 } \\
\hline \multirow{2}{*}{ Plant height } & $x^{-}$ & 112.86 & 114.53 & 108.16 & 121.19 & 125.56 \\
\hline & S2 & 1.28 & 2.23 & 1.21 & 251.74 & 133.57 \\
\hline \multirow{2}{*}{ Spike length } & $x^{-}$ & 17.90 & 17.73 & 19.26 & 12.80 & 11.98 \\
\hline & S2 & 1.00 & 0.89 & 1.00 & 3.73 & 2.99 \\
\hline \multirow{2}{*}{ No. of grain/spike } & $x^{-}$ & 87.38 & 99.60 & 92.60 & 63.11 & 70.48 \\
\hline & S2 & 98.46 & 50.37 & 39.68 & 242.15 & 201.02 \\
\hline \multirow{2}{*}{ No. of spikes/plant } & $x^{-}$ & 9.40 & 7.30 & 13.26 & 12.42 & 11.01 \\
\hline & S2 & 0.71 & 0.41 & 1.37 & 12.06 & 11.17 \\
\hline \multirow{2}{*}{ 1000-grains weight } & $x$ & 41.64 & 45.10 & 50.26 & 48.11 & 46.07 \\
\hline & S2 & 1.45 & 1.73 & 1.02 & 22.73 & 10.67 \\
\hline \multirow{2}{*}{ Grain yield/plant } & $x$ & 34.67 & 40.21 & 42.60 & 45.75 & 44.95 \\
\hline & S2 & 4.63 & 11.65 & 11.68 & 243.45 & 147.73 \\
\hline
\end{tabular}

No.of spikes/plant, No.of grainss/spike and 1000-grain weight are the main components of grains yield/plant. Hence, heterotic increase, if found, in one or more of these attributes with others being constant would lead to favorable yield increase in a hybrid. The lack of significance in heterosis of No.of grainss/spike in the third cross and 1000-grain weight in the first cross could be due to the lower magnitude of the non-additive gene action. These results are in agreement with those obtained by Abdel-Nour, Nadya and Moshref (2006). 
Koumber, R. M. and A.A. El-Gammaal

3

420 
Concerning potence ratio, Table 3 revealed that over domenance for all characters except plant height and 1000-grain weight in the first cross, spike length in the second cross and No.of grains /spike in the third cross which their potence ratio were less than unity indicating partial domenance effect. These results are in agreement with those obtained by Hendawy (2003).

Inbreeding depression were obtained in two out of three crosses for spike length, No.of grains/spike, No.of spikes/plant, 1000-grain weight and grain yield/plant and in one out of the three crosses for plant height. This is a valid result, since the expression of heterosis in the $F_{1}$ may be followed by reduction in $\mathrm{F}_{2}$ performance. The obtained results for most crosses were in harmony with those obtained by Abdel-Nour, Nadya and Moshref (2006). Morever, significant positive heterosis and significant negative inbreeding depression for these traits in one/two crosses were detected. The contradiction between heterosis and inbreeding depression estimates could be due to the presence of linkage between genes in these materials (Van der Veen, 1959).

Nature of gene action was determined using the five parametars Table 3. The estimated mean effect of $F_{2}(m)$ which reflects the contribution due to the over all mean plus the locus effects and ineractions of the fixed loci, was found to be highly significant. The additive gene effect (d) was significantly positive for plant height and 1000-grain weight in the first cross and for No.of spikes/plant in the third cross. Meanwhile, (d) was significantly negative for all the other traits in all crosses. These results suggest the potential for obtaining further improvement for the former traits by using pedigree selection program. Similar trend were obtained by Hendawy (2003).

Dominance gene effect $(\mathrm{h})$ was positive significant for all traits except for plant height in the first and third crosses, spike length in the fist cross, No.of grains/spike and grain yield/plant in third cross and No.of spikes/plant and 1000-grain weight in the second cross. The significant in these components indicated that both additive and dominance gene effects are important in the inheritance of these traits. Therfore, selection of desired traits could be practiced in the early generation but would be more effective in the late ones. These results are in agreement with those obtained by Abdel-Nour, Nadya and Moshref (2006).

Dominance $x$ dominance (I) type of gene was significant for No.of grains/spike in all three crosses, spike length in the first and second crosses, plant height in the first cross and 1000-grain weight in the second one. These indicates that dominance genetic effects were more important in the inheritance of these traits.

A significant additive $x$ additive type of epistasis (i) was detected for spike length in the second and third crosses, No.of grains/spike in the first and second crosses and 1000-garin weight in the first one.

The important roles of both additive and non-additive gene action in certain studied traits indicated that selection procedures based on the accumulation of additive effects would be very successful in improving these traits. Similar approaches were reported by Moustafa (2002) and Hendawy (2003). 


\section{Koumber, R. M. and A.A. El-Gammaal}

Significant positive $F_{2}$ deviation $\left(E_{1}\right)$ were indicated for plant height in the third cross, No.of spikes/plant in the second and third crosses and 1000grain weight in the first and third crosses. Meanwhile, significant negative values were obtained for spike length and No.of grains/spike in all crosses, plant height in the second cross and grain yield in the first one. These results may refer to the contribution of epistatic gene effects in the performance of these traits.

With regard to $F_{3}$ deviation $\left(E_{2}\right)$ was revealed to be significantly positive for plant height in the first and third crosses, No.of spikes/plant and 1000grain weight in the second one and grain yield in the second and third crosses. Morever, significant negative values were indicated for all traits of all crosses except for No.of spikes/plant in the third cross and 1000-grain weight in the first one. These results would ascertain the presence of epistasis in such large magnitude as to warrant great deal of attention in breeding programs.

Hertabilty in both broad and narrow senses, and between generations (parent off-spring regression) are presented in Table 4. High hertability values in broad sense were deetected for all the studied traits except for spike length in all crosses, No.of grains/spike in the second and third crosses, No.of spikes/plant in the first and second crosses and 1000-grain weight in the first and second crosses. Heritability estimates have been found to be useful in indicating the relative value of selection based on phenotypic expression of different characters, Kahrizi et al. (2010).

Table 4: Heritability and expected versus actual gain for all studied characters in three cross of bread wheat.

\begin{tabular}{|c|c|c|c|c|c|c|c|c|}
\hline \multirow{2}{*}{ Characters } & \multirow{2}{*}{ Crosses } & \multicolumn{2}{|c|}{ Heritability \% } & \multirow{2}{*}{\begin{tabular}{|c|}
$\begin{array}{c}\text { Parent off } \\
\text { spring }\end{array}$ \\
regression \\
\end{tabular}} & \multicolumn{2}{|c|}{ Expected gain } & \multicolumn{2}{|c|}{ Actual gain } \\
\hline & & \begin{tabular}{|l|} 
Broad \\
sense
\end{tabular} & $\begin{array}{c}\text { Narrow } \\
\text { sense }\end{array}$ & & \begin{tabular}{|c|} 
Delta \\
g
\end{tabular} & $\%$ of $\mathrm{F} 2$ & Delta g & $\%$ of $\mathrm{F} 3$ \\
\hline \multirow{3}{*}{ Plant height } & 1 & 88.508 & 45.76 & 52.10 & 12.74 & 10.60 & 12.74 & 10.48 \\
\hline & 2 & 94.44 & 73.28 & 31.61 & 30.04 & 25.48 & 10.31 & 28.36 \\
\hline & 3 & 99.375 & 93.88 & 58.20 & 30.69 & 25.32 & 13.86 & 24.44 \\
\hline \multirow{3}{*}{ Spike length } & 1 & 63.106 & 27.66 & 51.69 & 0.83 & 7.39 & 1.45 & 6.48 \\
\hline & 2 & 65.716 & 68.79 & 34.84 & \begin{tabular}{|l|}
2.95 \\
\end{tabular} & 21.37 & 1.21 & 24.15 \\
\hline & 3 & 74.256 & 39.78 & 29.18 & 1.58 & 12.37 & 1.04 & 13.22 \\
\hline \multirow{3}{*}{$\begin{array}{c}\text { No. of } \\
\text { grains/spike }\end{array}$} & 1 & 86.768 & 73.14 & 24.70 & 27.42 & 34.30 & 7.38 & 36.22 \\
\hline & 2 & 76.628 & 9.51 & 55.77 & 3.73 & 4.92 & 21.34 & 5.10 \\
\hline & 3 & 74.050 & 33.98 & 49.05 & 10.89 & 17.26 & 14.33 & 15.45 \\
\hline \multirow{3}{*}{$\begin{array}{c}\text { No. of } \\
\text { spikes/plant }\end{array}$} & 1 & 78.371 & 68.69 & 42.37 & 4.82 & 43.20 & 2.41 & 55.12 \\
\hline & 2 & 79.066 & 81.46 & 28.40 & 5.81 & 51.36 & 1.56 & 51.12 \\
\hline & 3 & 93.097 & 14.81 & 76.73 & 1.06 & 8.53 & 5.28 & 9.63 \\
\hline \multirow{3}{*}{$\begin{array}{c}\text { 1000-grains } \\
\text { weight }\end{array}$} & 1 & 81.398 & 27.39 & 28.26 & 2.58 & 5.08 & 2.48 & 5.53 \\
\hline & 2 & 71.562 & 86.89 & 29.59 & 8.47 & 14.44 & 2.17 & 18.16 \\
\hline & 3 & 93.84 & 62.13 & 23.42 & 6.10 & 12.68 & 1.91 & 13.24 \\
\hline \multirow{3}{*}{ Grain yield/plant } & 1 & 95.048 & 45.66 & 61.30 & 17.82 & 36.32 & 21.01 & 41.40 \\
\hline & 2 & 94.492 & 3.87 & 66.44 & 1.43 & 2.96 & 24.27 & 2.92 \\
\hline & 3 & 96.171 & 78.64 & 48.97 & 25.28 & 55.24 & 12.26 & 56.23 \\
\hline
\end{tabular}


High to moderate estimates of narrow sense heritabilty and parent offspring regression was found for all studied traits except for spike length and 1000 -grain weight in the first cross, No.of grains/spike and grain yield/plant in the second cross and No.of spikes/plant in the third one. The differences in magnitude of both narrow sense and parent off-spring regression heritabilty estimates for all the studied traits would ascertain the presence of both additive and non-additive gene effects in the inheritance of these traits. Similar conclusions were also reported by Abdel-Nour, Nadya et al. (2005).

The expected versus actual genetic gain for all traits were estimated. The expected genetic advance $\left(\Delta g \%\right.$ of $\left.F_{2}\right)$ ranged from 0.83 for spike length in the first cross to 30.69 for plant height in the third cross and actual genetic advance $\left(\Delta g \%\right.$ of $\left.F_{3}\right)$ ranged from 1.04 for spike length in the third cross to 24.27 for grain yield/plant in the second cross. The results of expected genetic advance upon selection were higher for plant height in the second and third crosses, No.of grains/spike in the first one and grain yield/plant in the first and third crosses. Also, the results of actual genetic advance were higher for No.of grains/spike in the second cross and grain yield/plant in the first and third crosses. These results indicated the possibilty of practicing selection in early generations to enhance these traits and hence selection high yielding genotypes. Dixit et al. (1970) pointed out that high heritabilty is not always associated with high genetic advance, but in order to make effective selection, high heritabilty should be associated with high genetic gain. Manal (2009) pointed out that the traits which had high heritability and also showed high expected genetic advance could be substantially considered or making selections as these traits were mainly influenced by the major effects of additive gene action.

Generally, the most biometrical parameters resulted from the all crosses had high values for most traits. Consecquently it could be concluded that these crosses would be of interest in a breeding program for genetic improvement of wheat.

\section{REFERENCES}

Abdel Nour, Nadya A. R.; H. A. Ashoush and Sabah H. Abo Elela (2005). Diallel crosses analysis for yield and its components in bread wheat. J. Agric. Sci., Mansoura Univ., 30 (1): 5725-5738.

Abdel Nour, Nadya A. R. and M.Kh. Moshref (2006). Gene effects and variances in three wheat crosses using the five parameters model. Egypt. J. plant breeding, 10 (1):305-318.

Akhtar, N. and M.A. Chowdhry (2006). Genetic analysis of yield and some other quantitative traits in bread wheat. Int. J. Agric. Biol., 8(4):523527.

Dixit, P.K; P.D. Saxena and I.K. Bhatia (1970). Estimation of genotypic variability of some quantitative characters in groundnut. Indian J. Agric. Sci., 40:197-201. 
Elhosary, A. A.; M. E. Raid; Nagwa A. Rady and Manal A. Hassan (2000). Heterosis and combining ability in durum wheat. Proc. 9 th Conf. Agron., Minufiya Univ., Sep. : 101-107.

Hayman, B. I. (1958). The separation of epistatic from additive and dominance variation in generation means. Heredity 12:371-390.

Hendawy, H.I. (2003). Genetic architecture of yield and its components and some other agronomic traits in bread wheat. Minufiya J. Agric. Res., 28 (1): 71-86.

Johanson, H. W.; H. F. Robinson and R. E. Comstock (1955). Estimates of genetic and environmental variability in Soybeans. Agron . J. $47: 314$ 318.

Kahrizi, D.; k. Cheghamirza; M. Kakaei; R. Mohammadi;A. Ebadi (2010). Heritability and genetic gain of some morphophysiological variables of durum wheat (Triticum turgidum var. durum). African J. Biotech. 9(30): 4687-4691

Manal, H. E. (2009). Estimation of heritability and genetic advance of yield traits in wheat (Triticum aestivum L.) under drought condition. J. Genetics and Molecular Bio. 1 (7) pp. 115-120

Mather, K. (1949). Biometrical Genetics. Dover Publications Inc., London.

Mather, K. and J.L. Jinks (1971). Biometrical Genetics. $3^{\text {rd }}$ Ed. Chapman and Hall, London .

Miller, P. A.; J. C. Williams; H. F. Robinson and R. E. Comstock (1958). Estimates of genotypes and environmental variances in upland cotton and their implications in selection. Agron. J., 50: 126-131.

Moustafa, M. A. (2002). Gene effect for yield and yield components in four durum wheat crosses. J. Agric. Sci., Mansoura Univ., 27(1):151-164.

Peter, F. C. and K. J. Frey (1966). Genotypic correlation, dominance and 259-262.

Sakai, K. I. (1960). Scientific basis of plant breeding. Lectures given at the Fac. of Agric., Cairo Univ. and Alex Univ.

Singh, R. K. and B. D. Chaudhary (1985). Biometrical Methods in quantitative Genetic Analysis. Kalyani Puplisher, New Delhi, Ludhiana, India.

Van der Veen, J. H. (1959). Test of non-allelic interaction and linkage for quantitative characters in generations derived from two, diploid pure lines. Genetica, 30: 201-232. 


\section{طبيعة التوارث والفعل الجينى للمحصول ومكوناته لثثلاثة هجن من قمح الخبز

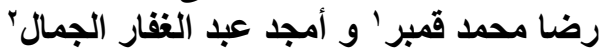

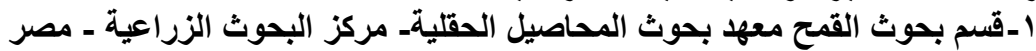

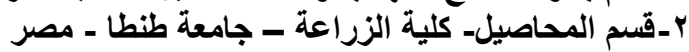

الهذف من إجراء هذا البحث هو دراسة التباين الور اثى ، و الفعل الجينى ، ودرجة التوريث

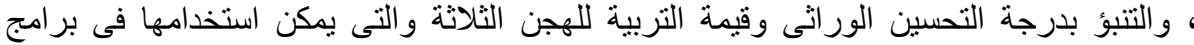

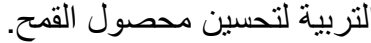

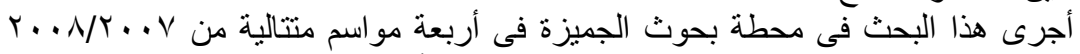

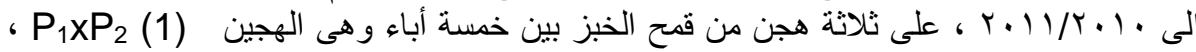

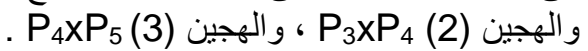
و واثنتلت الدر استة على كل من الأبوين و الجيل الأول ، و والثانى ، و والثالث

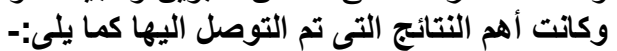

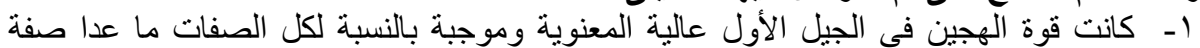

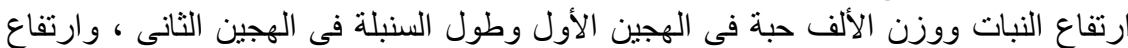

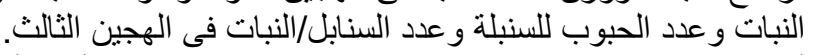

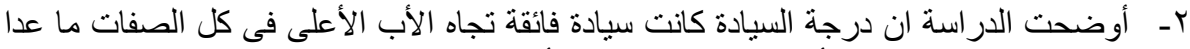

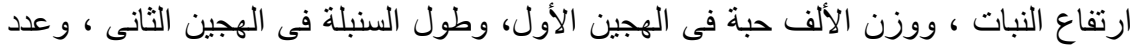

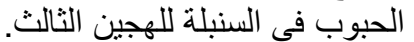

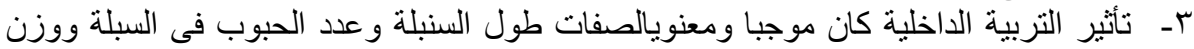
الالف حبة ومحصول الحبوب/النبات فى هجينان من ثلاثثة، ولهجين واحد فقط لصفة ارتفاع الكاع عـ - أظهرت التأثير ات الوراثية المضيفة وكذلك الفعل الجينى غير المضيف دورا هاما فى وراثة

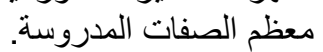
هـ كانت انحر افات الجيل الثانى (E)

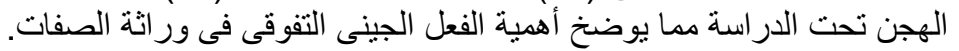

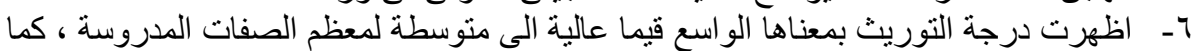

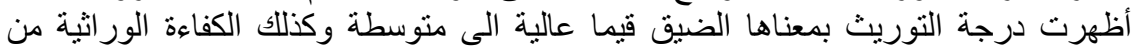

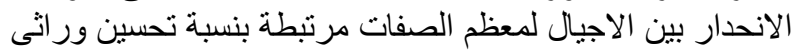

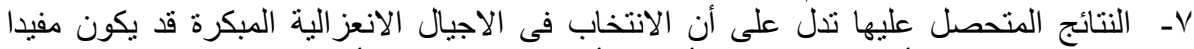
ولكن سوف يكون أكثر كفاءة اذا تم تأجيلة للأجيال الانعز الية المتأخرة.

كلية الزراعة - جامعة المنصورة

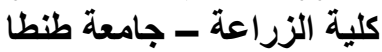

قام بتحكيم البحث

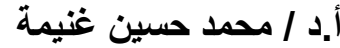

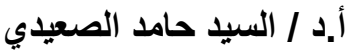



Table 3: Heterosis, potence ratio, inbreeding depression and gene action parameters for the three bread wheat crosses

\begin{tabular}{|c|c|c|c|c|c|c|c|c|c|c|c|}
\hline \multirow{2}{*}{ Characters } & \multirow{2}{*}{ Crosses } & \multirow{2}{*}{$\begin{array}{c}\text { Heterosis } \\
\text { M.P }\end{array}$} & \multirow{2}{*}{$\begin{array}{l}\text { potence } \\
\text { ratio }(P)\end{array}$} & \multirow{2}{*}{$\begin{array}{c}\text { Inbreeding } \\
\text { depression } \\
\%\end{array}$} & \multicolumn{7}{|c|}{ Gene action parameters } \\
\hline & & & & & m & d & h & $\mathbf{I}$ & i & E1 & E2 \\
\hline \multirow{3}{*}{ Plant height } & 1 & -1.31 & -0.25 & -1.23 & $109.79^{\star *}$ & $5.67^{* *}$ & $-32.25^{\star *}$ & $59.15^{\star *}$ & $-19.46^{* *}$ & 0.62 & $24.76^{\star \star}$ \\
\hline & 2 & $15.84^{\star \star}$ & 1.43 & $12.83^{\star *}$ & $117.91^{* *}$ & $-12.90^{* *}$ & $43.49^{\star *}$ & $-17.54^{* \star}$ & -0.81 & $-8.11^{* \star}$ & $-40.16^{\star *}$ \\
\hline & 3 & -4.87 & -6.64 & $-12.04^{\star \star}$ & $121.19^{\star *}$ & $-0.83^{\star *}$ & $-20.35^{\star *}$ & -11.41 & $-16.48^{* *}$ & $10.26^{\star *}$ & $29.27^{\star *}$ \\
\hline \multirow{3}{*}{ Spike length } & 1 & $28.07^{\star *}$ & 58.99 & $39.25^{\star \star}$ & $11.28^{\star *}$ & -0.07 & 0.63 & $27.89^{* \star}$ & $-3.58^{* *}$ & $-5.25^{\star \star}$ & $-7.34^{\star \star}$ \\
\hline & 2 & 2.63 & 0.39 & 11.57 & $13.83^{\star *}$ & $-1.03^{\star *}$ & $5.46^{\star \star}$ & $-3.68^{*}$ & $2.99^{* *}$ & $-1.61^{\star \star}$ & $-6.41^{\star \star}$ \\
\hline & 3 & $08^{\star *}$ & 17.32 & $33.56^{\star \star}$ & $12.80^{\star *}$ & 0.08 & $6.49^{* *}$ & $12.86^{\star *}$ & $5.22^{\star *}$ & $-5.74^{\star \star}$ & $-13.12^{* *}$ \\
\hline \multirow{3}{*}{$\begin{array}{l}\text { No. of } \\
\text { grains/spike }\end{array}$} & 1 & $26.01^{* *}$ & 44.27 & $35.32^{\star \star}$ & $79.95^{\star \star}$ & -0.58 & $40.42^{\star \star}$ & $93.77^{\star \star}$ & $13.76^{\star \star}$ & $-30.90^{\star *}$ & $-70.28^{\star *}$ \\
\hline & 2 & $22.19^{\star \star}$ & 44.54 & $37.36^{\star \star}$ & $75.84^{\star *}$ & 0.49 & $37.65^{\star \star}$ & $105.66^{\star *}$ & $16.65^{\star *}$ & $-34.25^{\star *}$ & $-74.11^{\star *}$ \\
\hline & 3 & -0.95 & -0.15 & 31.85 & $63.11^{\star *}$ & $-6.11^{\star *}$ & 0.00 & $117.96^{\star *}$ & $-11.33^{* *}$ & $-29.94^{\star *}$ & $-45.13^{\star *}$ \\
\hline \multirow{3}{*}{$\begin{array}{c}\text { No. of } \\
\text { spikes/plant }\end{array}$} & 1 & $63.34^{\star *}$ & & $17.36^{\star \star}$ & $11.16^{\star *}$ & $-1.14^{\star \star}$ & $8.03^{\star *}$ & $-6.69^{\star *}$ & 0.53 & 0.27 & $-4.31^{\star *}$ \\
\hline & 2 & 20 & & $-13.54^{\star \star}$ & $11.31^{\star *}$ & $-1.14^{\star \star}$ & -0.74 & -3.92 & $-4.71^{\star *}$ & $2.20^{\star \star}$ & $4.27^{* *}$ \\
\hline & 3 & $58.76^{\star \star}$ & & & $12.42^{\star \star}$ & $1.05^{\star *}$ & $4.33^{\star \star}$ & $-5.32^{*}$ & 1.52 & $1.62^{\star \star}$ & 0.40 \\
\hline \multirow{3}{*}{$\begin{array}{c}\text { 1000-grain } \\
\text { weight }\end{array}$} & 1 & & & & $50.85^{\star \star}$ & $1.22^{\star \star}$ & $7.97^{\star \star}$ & $-34.39^{\star *}$ & $11.34^{\star *}$ & $4.15^{\star *}$ & 0.01 \\
\hline & 2 & 20.8 & & 7 & 45.9 & $-0.77^{*}$ & 0.57 & $13.29^{\star \star}$ & $-9.51^{\star \star}$ & 0.66 & $2.70^{* \star}$ \\
\hline & 3 & & & & $48.11^{\star *}$ & $-1.73^{\star *}$ & $6.88^{* *}$ & -5.17 & $-3.47^{\star *}$ & 1.3 & $-1.49^{\star *}$ \\
\hline \multirow{3}{*}{ Grain yield/plant } & 1 & & & $* \star$ & $49.05^{\star *}$ & $-11.41^{\star *}$ & $23.33^{\star \star}$ & $-2.87^{\star \star}$ & $-15.34^{\star *}$ & $-3.03^{*}$ & $-18.08^{* *}$ \\
\hline & 2 & & & $18.27^{\star \star}$ & $48.14^{\star \star}$ & $-5.06^{\star *}$ & $5.47^{*}$ & 32.11 & $-31.87^{\star *}$ & & $6.97^{* *}$ \\
\hline & 3 & $13.77^{\star \star}$ & 1.86 & $-7.41^{* *}$ & $45.75^{\star \star}$ & $-2.77^{\star \star}$ & 0.03 & -12.70 & $-10.66^{\star *}$ & $5.74^{\star *}$ & $9.87^{* *}$ \\
\hline
\end{tabular}

